\title{
Semen Characteristics of Rabbit Bucks Orally Administered Exogenous L-Selenomethionine
}

\author{
E. O. Ewuola ${ }^{1^{*}}$ and D. E. Akinyemi ${ }^{1}$ \\ ${ }^{1}$ Animal Physiology and Bioclimatology Unit, Department of Animal Science, University of Ibadan, \\ Ibadan, Oyo State, Nigeria.
}

\section{Authors' contributions}

This work was carried out in collaboration between both authors. Author EOE designed the study, wrote the protocol, supervised the work and rewrite the manuscript. Author DEA performed the statistical analysis, managed the analyses of the study and wrote the first draft of the manuscript with the literature searches. Both authors read and approved the final manuscript.

Article Information

DOI: $10.9734 / A R R B / 2017 / 19196$

Editor(s):

(1) Xiao-Xin Yan, Department of Anatomy \& Neurobiology, Central South University Xiangya School of Medicine (CSU-XYSM),

Changsha, China.

(2) George Perry, Dean and Professor of Biology, University of Texas at San Antonio, USA.

Reviewers:

(1) Michele Kimie Sankako, Campinas State University, Brazil.

(2) Alejandro Córdova Izquierdo, Universidad Autónoma Metropolitana Unidad Xochimilco, Mexico.

(3) Engin Deveci, Dicle University, Diyarbakır, Turkey.

(4) Fernanda Carlini Cunha dos Santos, Universidade Federal de Pelotas, Rio Grande do Sul, Brasil.

(5) William Waissmann, National School of Public Heath, Brazil. Complete Peer review History: http://www.sciencedomain.org/review-history/19426

Original Research Article

Received $29^{\text {th }}$ May 2015

Accepted 14 ${ }^{\text {th }}$ April 2017

Published $9^{\text {th }}$ June 2017

\section{ABSTRACT}

An experiment was carried out to evaluate the semen quality of rabbits administered varied levels of exogenous L-Selenomethionine (L-SeMet). Twenty four male rabbits (10 months old) were randomly allotted to four treatments in a completely randomised design. Treatment 1 (control) was without exogenous L-SeMet, while treatments 2,3 and 4 were administered $0.2 \mathrm{mgkg}^{-1}, 0.3 \mathrm{mgkg}^{-1}$ and $0.4 \mathrm{mgkg}^{-1}$ oral supplementation of L-SeMet, respectively at 48hours interval for 6 weeks. Semen samples were collected at day 21 and day 42 using artificial vagina from the bucks and assessed for volume, mass activity, progressive motility, percentage dead and live sperm cells and sperm concentration. Sperm progressive motility and sperm concentration increased significantly $(P<0.05)$ as the concentration of $L-S e M e t$ increases at day 21. However, percentage dead sperm cells significantly $(P<0.05)$ reduced with increase in the level of $L-S e M e t$ supplementation. At day 42 , it was also observed that mass activity, sperm progressive motility and sperm concentration 
were significantly $(\mathrm{P}<0.05)$ highest in rabbits administered $0.4 \mathrm{mgkg}^{-1} \mathrm{~L}-\mathrm{SeMet}$. However, semen volume was not significantly different among the treatments on both days of assessment. This suggested that exogenous supplementation of L-SeMet up to $0.4 \mathrm{mgkg}^{-1}$ improved semen attributes and sperm cells formation of the rabbit bucks.

Keywords: Selenium; L-Selenomethionine; semen; sperm cell; rabbit bucks.

\section{INTRODUCTION}

Required for optimum growth and reproduction of animals are a number of inorganic elements classified as micronutrients and macronutrients [1]. The latter consisting calcium phosphorus, sodium and chloride are crucial to structural components of the bone and other tissues, as well as components of body fluids $[1,2]$. They are involved in the maintenance of acid-base balance, osmotic pressure, membrane electric potential and nervous transmission. The former, consists of cobalt, copper, iodine, iron, manganese, molybdenum, fluoride, chromium, potassium, sulphur and selenium [1,2,3]. Found in the body in very low concentrations, they serve as metaloenzymes component, enzyme cofactors or as components of hormones of the endocrine system [1].

The importance of Selenium (Se) as a trace mineral in animals and humans alike cannot be over-emphasised owing to its involvement in very many biological processes in the body. It is an important and indispensable component of selenoproteins [4] and glutathione peroxidase [5]. Existent in two forms (inorganic and organic), Se is actively involved in the defence of living tissues against the activities of free radicals. Se functions to prevent the occurrence of diseases such as exudative diathesis, white muscle disease, liver necrosis, muscular dystrophy in various animals, likewise the prevention of cancer and Keshan disease in humans $[6,7,3]$.

In addition, Se is also involved in reproductive functions. Fertility, embryonic implantation, placenta retention, sperm and testosterone synthesis are dependent on Se. In female animals, Se has been recorded to significantly increase fertility, reduce the amount of occurrence of ovarian cysts and uterine prolapse $[8,9,10]$. In male animals, Se deficiency is linked to an alteration in the synthesis of testosterone and sperm cells, fragility of the intermediate piece of sperm cell and reduction in sperm motility [11].
Se supplementation has been suggested as a means of providing the mineral to livestock. Mistry et al. [12] reported that there was increased fertility and improved semen quality after Se supplementation in humans, while Youcef et al. [13] reported an increase in the concentration, morphology and motility of sperm cells in humans exposed to inorganic Se. However, reproductive response of animals to organic Se is still a controversy, therefore this study was designed to evaluate the effect of organic Se in form of L-Selenomethionine on the semen characteristics of rabbit bucks.

\section{MATERIALS AND METHODS}

\subsection{Selenium Source}

L-Selenomethionine (Thorne Research, USA) containing $200 \mu \mathrm{g}$ Se per capsule was obtained for the purpose of the experiment.

\subsubsection{Experimental design and animals}

The study was carried out at the Rabbitry Unit of Teaching and Research Farm, University of Ibadan, Nigeria. The study was approved by the animal ethics and welfare committee of the institution. The site is located on 727' 00.4" N and 353 ' 34.2" E. Twenty four (24) adult rabbit bucks, 10 months old, were used for this experiment. They were allotted to four treatments after 4 weeks of adaptation, in a completely randomised design. Each treatment had six replicates. The animals were individually housed in metal cages. Treatment one (T1, Control) received no $\mathrm{Se}$ supplementation, while treatments 2 (T2), 3 (T3) and 4 (T4) had Se supplemented to the rabbits at $0.2 \mathrm{mgkg}^{-1}, 0.3$ $\mathrm{mgkg}^{-1}$ and $0.4 \mathrm{mgkg}^{-1}$ body weight respectively. All animals used for the experiment were provided with the same basal diet containing $17.78 \%$ crude protein, $2525.2 \mathrm{Kcal} / \mathrm{Kg}$ Digestible energy and $10.21 \%$ crude fibre. The test ingredient was dissolved into $2 \mathrm{ml}$ of water and administered orally in the morning, before feeding. This was done at 48- hour interval and lasted a period of six (6) weeks. 


\subsection{Semen Evaluation}

At days 21 and 42, semen was harvested from the bucks in the morning using artificial vagina. The evaluation of the ejaculate from the bucks was done immediately after collection. Volume was assessed using graduated syringe, which was rid of air bubbles afterwards and the value recorded. Sperm mass activity was determined with the aid of a binocular microscope (Olympus $\mathrm{CH}-2$ CHS Binocular Microscope, Olympus Corporation, Japan) at a magnification of $\mathrm{x} 100$ according to Ewuola and Egbunike (14). Mass activity was scored subjectively on a scale of "+" to " ++++ " according to the intensity of wave generated by the sperm cells. Sperm motility was evaluated according to the method of Ewuola and Egbunike (14) also with the aid of a microscope (Olympus $\mathrm{CH}-2$ CHS Binocular Microscope, Olympus Corporation, Japan) at Magnification of $x 400$. Progressively motile spermatozoa score was rated between 0 and $100 \%$.

Sperm concentration was evaluated with the use of a New Improved Neubauer Haemocytometer and a microscope (Avishkar AVI-504 Advance Research Binocular Microscope, Avishkar International, India) as outlined in Ewuola and Egbunike [14]. The ratio of live sperm cells to dead sperm cells was carried out by staining a drop of the ejaculate with eosin-nigrosin and then viewed under the microscope (Avishkar AVI-504 Advance Research Binocular Microscope, Avishkar International, India). Dead sperm cells absorbed the stain while live sperm cells did not. The percentage dead was obtained by multiplying the number counted for the dead in a field divided by the total number of sperm cells counted in that field multiplied by 100 . Percentage live sperm cells was obtained by subtracting the value of the percentage dead from 100 .

\subsection{Statistical Analyses}

Data collected were subjected to One-Way ANOVA of the Statistical Analysis System (SAS) software version 9.3 [15]. Significant differences between the treatment means were obtained using the Fisher's Least Significance Difference $\left(\alpha_{0.05}\right)$ option of the same software.

\section{RESULTS}

The semen volume, colour and mass activity of rabbits administered L-SeMet is presented in Table 1. The semen volume from the treated bucks was not significantly different from the bucks on the control at both days 21 and 42 . The semen colour of the bucks on T1, T2 and T3 was 'milky' while those on T4 were 'creamy white' at day 21 . However, at day 42 , the semen colour collected from all the experimental bucks was 'creamy white.' At day 21, mass activity was highest in the rabbit bucks on T3 and T4, while bucks on T2 had the same mass activity as those on T1. At day 42, the bucks on T2 was observed to have an increased sperm mass activity $(+++)$ compared to the control bucks $(++)$. The bucks on T3 and T4 had the highest mass activity $(++++)$.

There was significant $(P<0.05)$ difference in percentage motile sperm cells among the treatments at day 21 (Fig. 1). The rabbit bucks on T4 had significantly $(P<0.05)$ higher sperm motility (85.83\%) compared to the bucks on T2 $(70.83 \%)$. The control bucks had significantly $(\mathrm{P}<0.05) \quad$ lower sperm motility (63.33\%) compared with the bucks on T3 (82.50\%). There was no significant difference in the percentage sperm motility of the control bucks and those on T2. The percent live sperm cell was significantly $(P<0.05)$ influenced by $L-S e M e t$ across the treatments as shown in Fig. 2. Rabbit bucks on T4 had significantly $(\mathrm{P}<0.05)$ higher live sperm cells $(95.19 \%)$ than the bucks on T3 $(88.94 \%)$ at day 21. There was however, no significant difference between the live sperm cells of the bucks on T1 and T2. Sperm concentration of the bucks at day 21 was significantly $(P<0.05)$ different among the treatments (Fig. 3). The control bucks had significantly $(P<0.05)$ lower sperm concentration $\left(0.86 \pm 3.0 \times 10^{9} / \mathrm{ml}\right)$ than those on T4, while there was no significant difference between the sperm concentration of the bucks on T2 and T3.

At day 42, percent motile sperm cells was significantly $(P<0.05)$ lower in the control bucks $(45.83 \%)$ than those on T3 $(79.17 \%)$ and T4 $(78.33 \%)$. Percentage live sperm cells of the bucks on L-SeMet treatments were not significantly different from those on the control treatment. Sperm concentration was significantly $(\mathrm{P}<0.05)$ lower in the control rabbit bucks $(0.48 \mathrm{x}$ $\left.10^{9} / \mathrm{ml}\right)$ compared to those on T4 $\left(1.19 \times 10^{9} / \mathrm{ml}\right)$. There was no significant difference between the sperm cell concentration of bucks on T2 and T3.

\section{DISCUSSION}

Semen volume was not significantly influenced at the $21^{\text {st }}$ and $42^{\text {nd }}$ day of the experiment by L- 
SeMet in this study. This is suggestive that supplementing L-SeMet to the bucks may probably have no significant effect on the rate of seminal fluid secretion by the accessory glands since the sperm motility and concentration were higher in treated bucks than the control. This agrees with the report of Echeverria-Alonso et al. [16] who observed no significant increase in the seminal volume of young boars fed selenium and vitamin $E$ supplementation during warm and fresh seasons. However, Kamel [17] reported that semen volume was significantly influenced in rabbit bucks provided a combination of selenium and folic acid supplementation. It was observed that $0.4 \mathrm{mgkg}^{-1} \mathrm{~L}$-SeMet supplementation resulted in a significant increase in the percentage live sperm cells at day 21 compared to the bucks on the control while an apparent increase was also observed at day 42 .

It was observed that there was a steady rise in the percentage sperm motility of the bucks on oral L-SeMet supplementation in a dose-dependent manner. The mammalian spermatozoa cell membrane possess a high content of polyunsaturated fatty acids [18], which predisposes spermatozoa to the deleterious effects of reactive oxygen species, lipid peroxides and free radicals, known to cause significant damage to sperm cells. Spontaneous lipid peroxidation causes the plasma membrane to lose its ability to act as a permeability barrier, leading to the loss of cytosolic enzymes and substrates and hence a decrease in sperm motility [19]. The improved livability and motility observed in the current study may probably be attributed to the protective effect of the increased activities of the selenium based antioxidant, glutathione peroxidase [20]. Glutathione peroxidase has been reported to help in alleviating the activities of reactive oxygen species, lipid peroxides and hyperoxides on the sperm cells which tend to cause damage to sperm cells [21,22]. This supports the work of ElMokadem et al. [23] who reported improved sperm motility as a result of Se supplementation in rams that were exposed to gossypol toxicity. It also agrees with the report of Simon [24] who observed that broiler breeders fed diets supplemented with L-SeMet had improved sperm motility. Marai et al. [25] reported that $0.1 \mathrm{ppm}$ sodium selenite supplementation resulted in an increase in sperm motility in rams. MarinGuzman et al. [26] also reported that $0.5 \mathrm{ppm}$ organic Se supplementation resulted in an increase in sperm motility of boars than the control group. However, this result is at variance with that of Horky [27] who reported that 0.3 $\mathrm{mgkg}^{-1}$ selenium supplementation did not influence sperm motility in breeding pigs. Sperm cell concentration observed in this study was significantly influenced by L-SeMet supplementation at day 21 and day 42 in a dosedependent manner. This suggested that selenium is highly essential in the spermatogenesis and also in the normal development of spermatozoa coupled with other biological functions in the Leydig cells [28]. This supports the findings of Hanafy et al. [29] who reported an increase in sperm concentration in cocks provided organic selenium supplementation and Kamel [17] also reported an increase in sperm concentration of rabbit bucks administered organic selenium, and a combination of selenium and folic acid. Edens [30] reported that the inclusion of selenium in poultry diet increases sperm cell count, and using an organic source reduces the production of abnormal sperm cells, thereby having a positive effect on the fertilizing potential of the male. This result corroborates the findings of Renema [31] who reported that feeding broiler breeder cocks between $45-65$ weeks of age with $0.2 \mathrm{mgkg}^{-1} \mathrm{Se}-\mathrm{Plex} \AA$ (an organic source of selenium) increased sperm production.

Table 1. Semen volume, colour and mass activity of rabbit bucks administered L-Selenomethionine at days 21 and $42(n=24$, Mean $\pm S D)$

\begin{tabular}{|c|c|c|c|c|}
\hline Parameters & T1 (0 mg/kg) & T2 $(0.2 \mathrm{mg} / \mathrm{kg})$ & T3 $(0.3 \mathrm{mg} / \mathrm{kg})$ & T4 (0.4 mg/kg) \\
\hline \multicolumn{5}{|l|}{ Day 21} \\
\hline Semen volume (ml) & $0.58 \pm 0.28$ & $0.67 \pm 0.17$ & $0.51 \pm 0.16$ & $0.49 \pm 0.18$ \\
\hline Semen colour & Milky & Milky & Milky & Creamy white \\
\hline $\begin{array}{l}\text { Mass activity } \\
\text { Day } 42\end{array}$ & ++ & ++ & ++++ & ++++ \\
\hline Semen volume (ml) & $0.29 \pm 0.21$ & $0.37 \pm 0.16$ & $0.45 \pm 0.13$ & $0.46 \pm 0.28$ \\
\hline Semen colour & Cream white & Cream white & Cream white & Cream white \\
\hline Mass activity & t+ & +++ & ++++ & ++++ \\
\hline
\end{tabular}




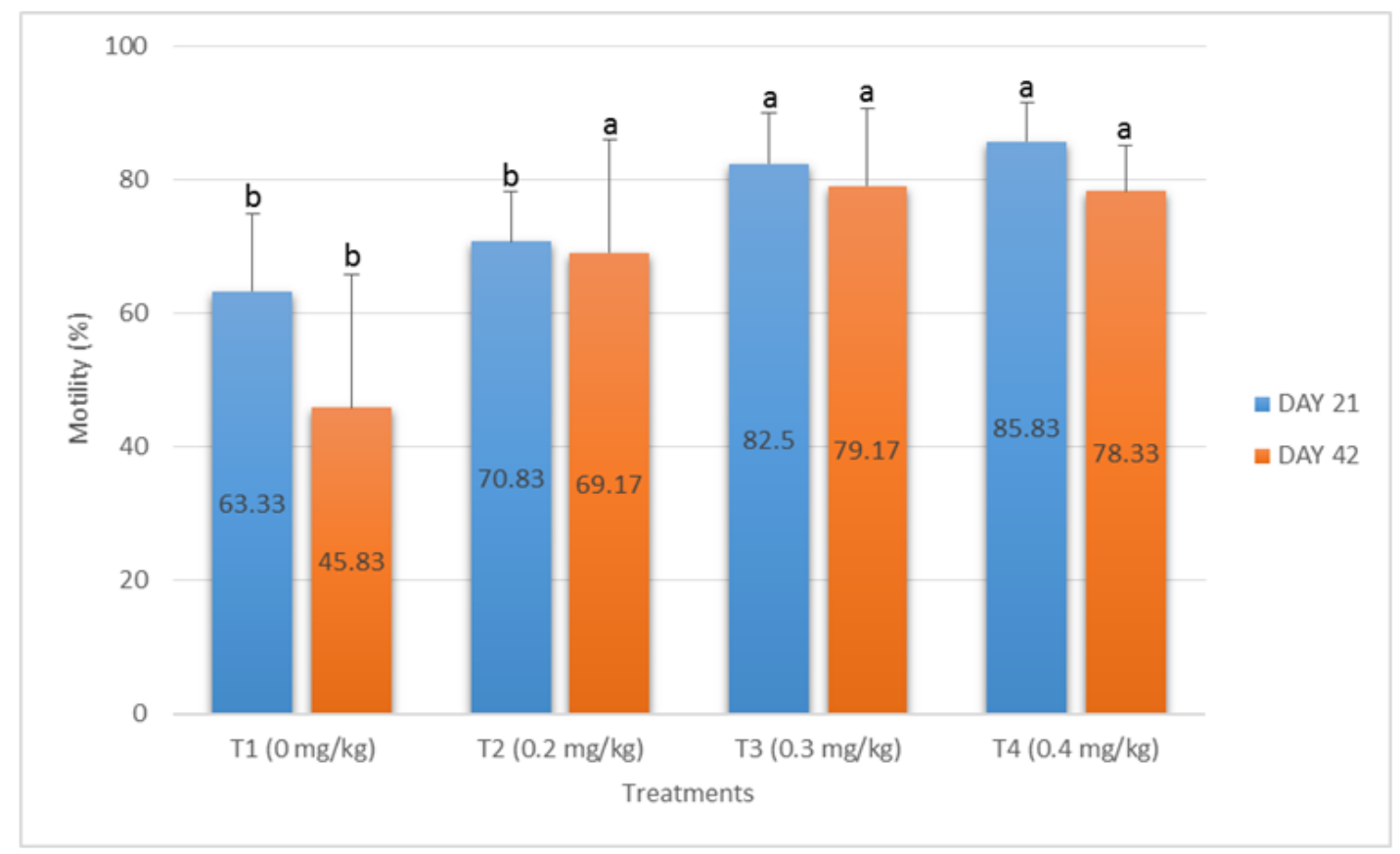

Fig. 1. Percentage motility of sperm cells of rabbit bucks administered L-Selenomethionine at days 21 and $42(n=24, \%)$

ab: means among the same bars that has different superscript are significantly $(p<0.05)$ different

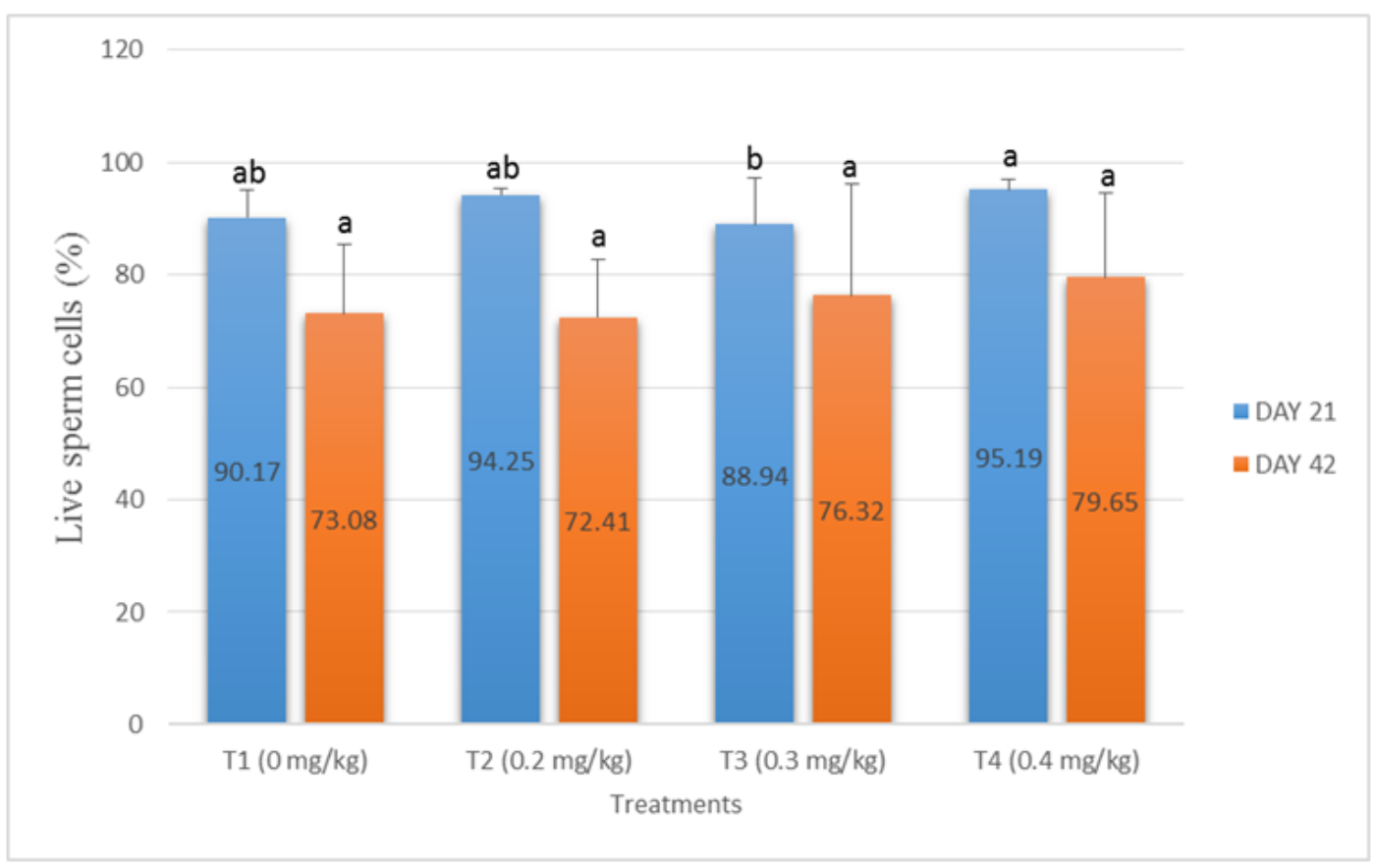

Fig. 2. Percentage live sperm cells of rabbit bucks administered supplemental levels of L-Selenomethionine $(n=24, \%)$

$a b$ : means among the same bars that has different superscript are significantly $(p<0.05)$ different 


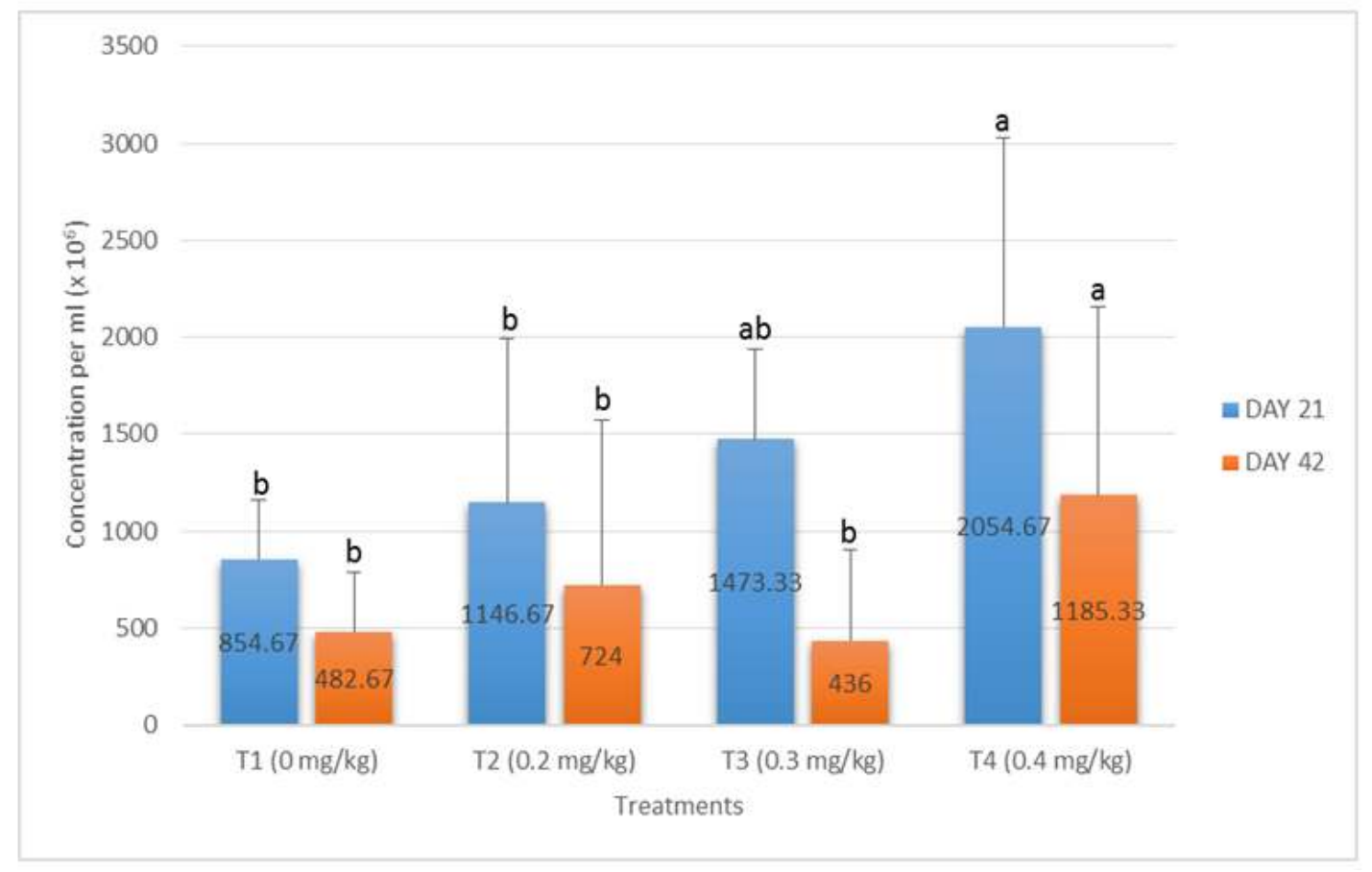

Fig. 3. Sperm concentration of rabbit bucks administered supplemental levels of L-Selenomethionine $(n=24$, Mean \pm SD)

$A b$ : means among the same bars that has different superscript are significantly $(p<0.05)$ different

\section{CONCLUSION}

This study showed that oral supplementation of organic selenium in the form of LSelenomethionine up to $0.4 \mathrm{mgkg}^{-1}$ to rabbit bucks improved sperm motility and concentration with potential increase in the reproductive efficiency of rabbit for breeding purpose.

\section{COMPETING INTERESTS}

Authors have declared that no competing interests exist.

\section{REFERENCES}

1. National Research Council. Nutrient Requirements of Dairy Cattle. Subcommittee on Dairy Cattle Nutrition, Committee on Animal Nutrition, Board on Agriculture, National Research Council. $7^{\text {th }}$ rev. ed. National Academy Press. Washington, D.C; 2001.

ISBN: 0-309-06997-1

2. Eruvbetine D. Canine nutrition and health. A paper presented at the seminar organized by Kensington
Pharmaceuticals Nig. Ltd., Lagos on August 21; 2003.

3. Soetan KO, Olaiya CO and Oyewole OE. The importance of mineral elements for humans, domestic animals and plants: A review. African Journal of Food Science. 2010;4(5):200-222.

4. Kryukov GV, Castellano S, Novoselov SV, Lobanov AV, Zehtab O, Guigo R, Gladyshev VN. Characterization of mammalian selenoproteomes. Science. 2003;300:1439-1443.

5. Murray RK, Granner DK, Mayes PA, Rodwell VW. Harper's Biochemistry, $25^{\text {th }}$ Edition, McGraw-Hill. Health Profession Division, USA; 2000.

6. Rayman MP. Selenium in cancer prevention: A review of the evidence. Proceedings of the Nutrition Society. 2005; 64:527-542.

7. Gupta RC. Veterinary Toxicology. Basic and Clinical Principles. Elsevier Academic Press; 2007.

ISBN: 978-0-12-370467-2

8. Harrison $\mathrm{JH}$, Conrad RH. Effect of dietary calcium on selenium absorption by the 
non-lactating dairy cow. J. Dairy Sci. 1984; 67:1860-1864.

9. Gutierrez C, Corbera JA, Morales I, Morales M, Navarro R. Uterine prolapse in 2 dromedary camels. Can. Vet. J. 2001; 42:803-804.

10. Meschy F. Nutrition minérale des ruminants. Editions Quae: Versaille, France. 2010;208.

11. Maiorino M, Aumann KD, Brigelius-Flohe R, Doria D, Van Den Heuvel J, McCarthy J, Roveri A, Ursini F, Flohe L. Probing the presumed catalytic triad of seleniumcontaining peroxidases by mutational analysis of phospholipid hydroperoxide glutathione peroxidase (PHGPX). Biol. Chem. Hoppe Seyler. 1995;376:651-660.

12. Mistry HD, Pipkin FB, Redman CW, Poston L. Selenium in reproductive health. Am. J. Obstet. Gynecol. 2012;206:21-30.

13. Youcef Mehdi, Jean-Luc Hornick, Louis Istasse Isabelle Dufrasne. Selenium in the environment, metabolism and involvement in body functions. Review - Molecules. 2013;18:3292-3311.

14. Ewuola EO, Egbunike GN. Effects of dietary fumonisin $B_{1}$ on the onset of puberty, semen quality, fertility rates and testicular morphology in male rabbits. Reproduction. 2010;139:439-445

15. Statistical Analysis System. SAS/STAT User's Guide. Version 9.3 for Windows. SAS Institute Inc. SAS Campus Drive, Cary, North Carolina, USA; 2011.

16. Echeverria-Alonso S, Santos-Ricalde R, Centurion-Castro F. Effects of dietary Selenium and Vitamin $E$ on semen quality and sperm morphology in young boars during warm and fresh season. Journal of Animal and Veterinary Advances. 2009;8 (11):2311-2317.

17. Kamel Kl. The effect of dietary organic selenium and folic acid supplementation on productive and reproductive performance of male rabbits under heat stress conditions. Egypt. Poult. Sci. 2012; 32:43-60.

18. Zalata A, Christophe A, Depuydt C, Schoonjans $\mathrm{F}$ and Comhaire F. The fatty acid composition of phospholipids of spermatozoa from infertile patients. Mol. Hum. Reprod. 1998;4:111-118.

19. Alvarez JG, Storey BT. Assessment of cell damage caused by spontaneous lipid peroxidation in rabbit spermatozoa. Biol. Reprod. 1984;30:323-331.

20. Irvine DS. Glutathione as a treatment for male infertility. Rev. Reprod. 1996;1:612.

21. Ursini $F$, Heim $S$, Kiess $M$, Maiorino M, Roveri A, Wissing J. Dual function of the selenoprotein PHGPx during sperm maturation. Science. 1999;285(5432): 1393-6.

22. Safarinejad MR, Safarinejad S. Efficacy of selenium and/or $\mathrm{N}$-acetyl-cysteine for improving semen parameters in infertile men: A doubleblind, placebo controlled, randomized study. J. Urol. 2009;181:74151.

23. EL-Mokadem MY, Taha TA, Samak MA, Yassen AM. Alleviation of reproductive toxicity of gossypol using selenium supplementation in rams. J. Anim. Sci. 2012;90:3274-3285.

24. Simon S. Alltech symposium highlights. World Poult. 2004;20:12-13.

25. Marai IFM, El-Darawany AA, Ismail EA, Abdel-Hafez MAM. Reproductive and physiological traits of Egyptian Suffolk rams as affected by selenium dietary supplementation and housing heat radiation effects during winter of the subtropical environment of Egypt. Arch. Tierz. 2009;52:402-409.

26. Marin-Guzman J, Mahan DC, Whitmoyer R. Effect of dietary selenium and vitamin $E$ on the ultrastructure and ATP concentration of boar spermatozoa, and the efficacy of added sodium selenite in extended semen on sperm motility. J. Anim. Sci. 2000;78:1544-1550.

27. Horky P. The effect of various forms (organic, inorganic) and levels of selenium on the laboratory values of the ejaculate of breeding boars in summer season. Res. Pig Breed. 2012;6:24-32.

28. Behne D, Weiler $H$, Kyriakopoulos $A$. Effects of selenium deficiency on testicular morphology and function in rats. Journal of Reproductive Fertility. 1996; 106:291-297.

29. Hanafy MM, El-Sheikh AMH, Abdalla EA. The effect of organic selenium (Sel-Plex ${ }^{\mathrm{TM}}$ ) On productive, reproductive and physiological traits of Bandarah Local Strain. Egypt. Poult. Sci. 2009;29(4):10611084. 
30. Edens FW. Practical applications for selenomethionine: Broiler breeder reproduction. In: Nutritional Biochemistry in the feed and food industries. Proceedings of Alltech's $18^{\text {th }}$ Annual Symposium (K.A. Jacques and T.P. Lyons, eds). Nottingham University Press, UK. 2002;29-42.
31. Renema RA. Creating the ideal hatching egg: Quality, efficiency and fertility. Nutritional biotechnology in the feed and food industries: Proceedings of Alltech's $22^{\text {nd }}$ Annual Symposium. 2006. Lexington, Kentucky, USA; 2006.

(0) 2017 Ewuola and Akinyemi; This is an Open Access article distributed under the terms of the Creative Commons Attribution License (http://creativecommons.org/licenses/by/4.0), which permits unrestricted use, distribution, and reproduction in any medium, provided the original work is properly cited.

Peer-review history:

The peer review history for this paper can be accessed here: http://sciencedomain.org/review-history/19426 